\title{
Tolerance of Arabica Coffee Cultivars for Aluminum in Nutritive Solution
}

\author{
Célia Maria Peixoto de Macedo ${ }^{1}$, José Carlos Lopes ${ }^{2 *}$, José Augusto Teixeira do Amaral ${ }^{2}$, \\ Aymbiré Francisco Almeida da Fonseca ${ }^{3}$ and José Francisco Teixeira do Amaral $^{2}$ \\ ${ }^{1}$ Laboratório de Fitotecnia; Centro de Ciências e Tecnologias Agropecuárias; Universidade Estadual do Norte \\ Fluminense Darcy Ribeiro; Campos dos Goytacazes; Rio de Janeiro - RJ - Brasil. ${ }^{2}$ Departamento de Produção \\ Vegetal; Universidade Federal do Espírito Santo; C. P.: 16; 29500-000; Alegre - ES - Brasil. ${ }^{3}$ Embrapa Café; \\ Empresa Brasileira de Pesquisa Agropecuária; Brasília -DF - Brasil
}

\begin{abstract}
This work aimed to evaluate the Coffea arabica cultivars for aluminum toxicity tolerance, in modified Hoagland solution. A completely randomized design with five repetitions in a factorial $4 x 4$ (cultivar $x$ combinations of aluminum) was used. After 44 days of the sowing, were transferred ten seedlings each cultivar germinated in the absence of $A l^{3+}$ to solution without $A l^{3+}$, and ten for solution with $A l^{3+}$; ten seedlings each cultivar germinated in presence of $A l^{3+}$ to solution without $A l^{3+}$, and ten for solution with $A l^{3+}$. In the treatment with aluminum, the element was added to the nutritive solution in the concentration of $0.83 \mathrm{mmol} \mathrm{L}^{-1}$ as $\mathrm{Al}_{2}\left(\mathrm{SO}_{4}\right)_{3} \cdot 16 \mathrm{H}_{2} \mathrm{O}$. The cultivars Catuai Amarelo IAC 62 and Iapar 59 were tolerant to the aluminum; cultivar Oeiras presented intermediate tolerance, while cultivar Obatã IAC 1669-20 was sensitive. The tolerance of the coffee cultivars to the aluminum during the initial development of the seedlings did not depend on the presence of aluminum in the germination phase.
\end{abstract}

Key words: Coffea arabica, aluminum toxicity, vigor, breeding

\section{INTRODUCTION}

Brazil is the largest coffee-producing country in the world, responsible for the development of many localities in the Espírito Santo state of Brazil (ABIC, 2006). According to CONAB (2008), Brazilian coffee production during the 2007/2008 harvest year was 33.7 million green coffee $60 \mathrm{~kg}$ bags, with mean productivity of 16.27 bags per hectare. However, this was low compared to its genetic productivity potential.

When fructification is low, plagiotropic branches and new leaves and branches replace fruit as a carbohydrate and nutrient sink (Malavolta et al., 2002), despite the fact that the supply, absorption and balanced use of the essential mineral nutrients are related to the $\mathrm{pH}$ and presence of exchangeable aluminum (Marschner, 2003). If the $\mathrm{pH}$ is not at the adequate range, nutrient deficiency and toxicity may occur and production would suffer, leading to decreased nutritional efficiency (Fageria, 1998). Considering that superficial lime application under the no-till cultivation system does not totally and adequately correct soil acidity deeper than $10 \mathrm{~cm}$ (Rheinheimer et al., 2000), a

*Author for correspondence: jcufes@bol.com.br 
viable alternative would be the use of aluminumtolerant species or cultivars (Foy et al., 1978).

$\mathrm{Al}^{3+}$ solubility increases under $\mathrm{pH}$ below 5.5 and its toxicity is particularly severe under $\mathrm{pH}$ below 5.0 (Fageria, 1998). Justino et al. (2006) found that $\mathrm{Al}^{3+}$ has a wide range of action on plant metabolism, this probably being the reason why its mechanism of action is not well known yet. However, it is known that the negative effect of aluminum does not affect calcium absorption directly but rather through root growth inhibition, decreasing $\mathrm{Ca}^{2+}$ absorption, regardless of the direct effect of aluminum on the absorption process (Menosso et al., 2000).

Braccini et al. (2000a), based on the evaluation of primary root length of 26 coffee lines submitted to $45 \mathrm{mg} \mathrm{L}^{-1}$ aluminum concentration, using the paper-solution method, found different levels of tolerance among the lines in relation to the presence of toxic aluminum.

Plant tolerance to aluminum is often associated to the plant's capacity to alter the $\mathrm{pH}$ in the rhizosphere (Degenhardt et al., 1998). Mendonça et al. (2005) used nutritive solutions in the absence and presence of aluminum at different rates of $\mathrm{NO}_{3}{ }^{-} / \mathrm{NH}_{4}{ }^{+}$, and showed that the differential tolerance to aluminum in two rice cultivars could be associated to their capacity to modify the $\mathrm{pH}$ of the nutritive solution.

The plant have wide ability to adapt for different agricultural ecosystems, deriving from several factors, such as economic, marginal area utilization and production stability (Menosso et al, 2000). Plant species germinating under certain conditions, such as in the presence of exchangeable aluminum, are likely able to acquire a greater capacity of tolerating the adverse effects of this element. The use of tolerant cultivars to soil $\mathrm{Al}^{3+}$ toxicity allows the commercial use of many marginal areas for cultivation. The differential tolerance to aluminum is a characteristic easily detected in greenhouse or laboratory tests using nutritive solution (Dornelles et al., 1997).

This work aimed to evaluate the Coffea arabica cultivars aluminum toxicity tolerance in nutritive solution.

\section{MATERIAL AND METHODS}

This work was carried out from December 2005 to March 2006. The seeds were obtained from Incaper experimental station in Venda Nova do
Imigrante. The experiment was conducted in a completely randomized design with five repetitions, each one constituted by two seedlings. Arabica coffee cultivars were distributed in the $4 \mathrm{x}$ 4 factorial scheme in four aluminum treatments: pre-treatment without aluminum during the germination and transplanted to a nutritive solution without aluminum (-Al / -Al); pretreatment without aluminum during the germination and transplanted to the nutritive solution with aluminum $(-\mathrm{Al} /+\mathrm{Al})$; pre-treatment with aluminum during the germination and transplanted to the nutritive solution without aluminum (+Al / -Al); pre-treatment with aluminum during the germination and transplanted to nutritive solution with aluminum $(+\mathrm{Al} /+\mathrm{Al})$.

The seedlings of the cultivars Catuaí Amarelo IAC 62, Iapar 59, Obatã IAC-1669/20 and Oeiras (MG 6851), derived from the seeds without parchment were removed manually and germinated in three Germitest ${ }^{\circledR}$ type tissues. The seeds were moistened (at the proportion of 2.5 times the tissue weight) with a nutritive solution which contained $\left(\mathrm{mmol} \mathrm{L}^{-1}\right) \mathrm{MgSO}_{4} 0.1, \mathrm{KNO}_{3} 0.1, \mathrm{NH}_{4} \mathrm{NO}_{3} 0.15$ and $\mathrm{KHC}_{8} \mathrm{H}_{4} \mathrm{O}_{8} 8.0$ (potassium biphthalate to maintain the $\mathrm{pH}$ around 4.0) with or without 0.83 mmol L ${ }^{-1}$ of $\mathrm{Al}^{3+}$ in the form of $\mathrm{Al}_{2}\left(\mathrm{SO}_{4}\right)_{3} \cdot 16 \mathrm{H}_{2} \mathrm{O}$. In order to prevent the fungus development, the seedlings were treated with the fungicide Captan (Orthocide $^{\circledR}$ ) at the concentration of $0.1 \%$. The seedlings were placed at the vertical position inside the plastic vases (1 liter volume), containing $300 \mathrm{ml}$ of nutritive solution at different levels of $\mathrm{Al}^{3+}$ so as to keep the tissue always moistened. The recipients were maintained in the dark inside the germinator at $30 \pm 1^{\circ} \mathrm{C}$.

After 44 days from the start of sowing, the uniform seedlings were selected, at the "match stick" stage to transplant to a hydroponic system, which at the primary root presented approximately six centimeter of length. Later, 10 seedlings of each cultivar, germinated in the absence of $\mathrm{Al}^{3+}$, were transferred to the nutritive solution in the absence and presence of $\mathrm{Al}^{3+}$, as well as 10 seedlings of each cultivar, germinated in the presence of $\mathrm{Al}^{3+}$, were transferred to the nutritive solution in the absence and presence of $\mathrm{Al}^{3+}$. The nutritive solution used was Hoagland and Arnon (1950), modified, containing macronutrients $\left(\mathrm{mmol} \mathrm{L}^{-1}\right): \mathrm{N}=7.5 ; \mathrm{P}=0.5 ; \mathrm{K}=3.0 ; \mathrm{Ca}=2.5$; $\mathrm{Mg}=1.0 ; \mathrm{S}=1.0$; and micronutrients $\left(\mu \mathrm{mol} \mathrm{L}^{-1}\right)$ : $\mathrm{Mn}=4.6 ; \mathrm{Cu}=0.2 ; \mathrm{Zn}=0.4 ; \mathrm{Mo}=0.06 ; \mathrm{B}=$ $23.1 ; \mathrm{Fe}$, in the form of $\mathrm{Fe}-\mathrm{EDTA}=0.05 ; \mathrm{Cl}=4.6$. 
In the aluminum treatment, the element was added to the nutritive solution at the concentration of $0.83 \mathrm{mmol} \mathrm{L}^{-1}$, in the form of $\mathrm{Al}_{2}\left(\mathrm{SO}_{4}\right)_{3} \cdot 16 \mathrm{H}_{2} \mathrm{O}$. The nutritive solutions were renewed after 21 days from the day the seedlings were transferred to the hydroponic system and the $\mathrm{pH}$ of the nutritive solutions was adjusted to $4.0 \pm 0.2$. The $\mathrm{P}$ concentration $\left(0.5 \mathrm{mmol} \mathrm{L}^{-1}\right)$ was low to minimize aluminum precipitation.

The hydroponic system was installed in a growth chamber under ambient temperature of $25 \pm 2^{\circ} \mathrm{C}$, relative humidity of $60 \%$ and $8 \mathrm{~h}$ photoperiod, using four 40 Watt fluorescent lights. Plastic vases of 1 liter were used, wrapped in aluminum paper. As supports for the seedlings, styrofoam plates with two holes were used, with each plantlet being supported by a styrofoam cylinder, longitudinally sectioned, with the same diameter of the plate's hole. The solution was aired through air bubbling in a continuous way supplied by a motorcompressor.

The completion of the treatment coincided with seedling collection after 42 days of transplant by sectioning them at the stem height. The height of the aerial part, primary root length, fresh and dry mass of the aerial part and root system of each repetition were evaluated. Dry mass was obtained after the different seedling parts were dried in an forced air circulation oven at $80 \pm 2^{\circ} \mathrm{C}$, until reaching constant weight. The RCR rate (root length percent reduction ratio) was calculated according to the equation below, suggested by Baligar et al. (1989):

$\%$ RCR $=[1$ - (Growth with Al / Growth without $\mathrm{Al})]$ x 100.

The experimental data were submitted to variance analysis and when significant, the means were compared by the Tukey test at $1 \%$ and 5\% probability, using the statistical software SAEG (Statistical Analyses Systems of the Universidade Federal de Viçosa - UFV), 9.0 version (Euclydes, 2004).The "Lilliefors" and"Cochran and Bartlett" tests were applied at $1 \%$ significance level to verify data normality and variance homogeneity, respectively.

\section{RESULTS AND DISCUSSION}

The highest $\mathrm{pH}$ values were observed in the nutritive solutions 21 days after solution exchange (42 days after of transplant). However, there was no daily adjustment of $\mathrm{pH}$. Without aluminum, regardless of the cultivar, the $\mathrm{pH}$ increased, on an average, in 3.0 units (Table 1). However, with aluminum, there was no alteration. These results suggested that $\mathrm{pH}$ variation was dependent on the absence or presence of aluminum in the medium, and that the different cultivars did not interfere in this variation, confirming the results of Braccini et al. (2000b).

Table 1 - Mean of the final $\mathrm{pH}$ values of the nutritive solutions in the absence $(-\mathrm{Al})$ and presence of aluminum $(+\mathrm{Al})$ of each Coffea arabica cultivar.

\begin{tabular}{lcc}
\hline \multirow{2}{*}{ Cultivars } & \multicolumn{3}{c}{ Final pH of the nutritive solution } \\
\cline { 2 - 3 } & $-\mathbf{A l}$ & $\mathbf{+ A l}$ \\
\hline Catuaí Amarelo IAC-62 & 7.2 & 3.9 \\
Iapar 59 & 7.0 & 3.8 \\
Obatã IAC-1669/20 & 7.0 & 3.9 \\
Oeiras MG-6851 & 6.8 & 3.9 \\
\hline Mean & 7.0 & 3.9 \\
\hline
\end{tabular}

The evaluation of the fresh mass of the seedling is related to the capacity of the cultivar to accumulate water under a particular condition. The treatment in the absence of aluminum during the germination and growth $(-\mathrm{Al} /-\mathrm{Al})$ represented the control, with the lowest FMAP values being observed in the cultivars Oeiras MG-6851 and Catuaí Amarelo IAC 62, indicating adaptation of cultivars Iapar-59 and Obatã IAC-1669/20 to neutral $\mathrm{pH}$ and aluminum zero soil (Table 2). In the treatment $-\mathrm{Al} /+\mathrm{Al}$ (pre-treatment without aluminum during the germination and transplanted to nutritive solution with aluminum), none of the cultivars presented significant difference in relation to FMAP. Cultivar Catuaí Amarelo IAC 62 presented a lower level of FMAP in the treatment with aluminum during the germination $(+\mathrm{Al} /-\mathrm{Al})$, not differing from the cultivar Oeiras MG 6851. However, a significant difference was observed between these two cultivars in the 
treatment $+\mathrm{Al} /+\mathrm{Al}$ (pre-treatment with aluminum during the germination and transplanted to nutritive solution with aluminum) indicating aluminum sensibility of 'Catuaí Amarelo IAC-62' and tolerance of Iapar-59', not differing from 'Oeiras MG-6851' and 'Obatã IAC-1669/20'.

Comparing the treatments with and without aluminum, for the cultivar Catuaí Amarelo IAC 62 in the both treatments in germination better growth occurred in aluminum nutritive solution, indicating tolerance. In the cultivar Iapar-59, the growth was same and good in both the nutritive solutions with and without $\mathrm{Al}+$ in germination and with and without after transplanting, better than 'Catuaí Amarelo IAC-62' indicating intermediate tolerance. Cultivar Obatã IAC-1669/20 developed better than 'Catuaí Amarelo IAC-62' but there was reduction in the growth when compared to nutritive solution without aluminum indicating sensitivity. Cultivar Oeiras MG 6851 presented statistically better growth with and without aluminum in the germination phase, indicating better tolerance than 'Iapar-59' (Table 2).

Table 2 - Fresh mass of the aerial part (FMAP) and root length (RL) of seedlings of Coffea arabica cultivars derived from seeds germinated in the absence and presence of aluminum and developed in the absence and presence of aluminum $^{(1)}$.

\begin{tabular}{lcccc}
\hline \multirow{2}{*}{ Cultivars } & \multicolumn{4}{c}{ FMAP $(\mathbf{m g}) * *$} \\
\cline { 2 - 5 } & $\mathbf{- A l} / \mathbf{- A l}$ & $\mathbf{- A l} / \mathbf{+ A l}$ & $\mathbf{+ A l} / \mathbf{- A l}$ & $\mathbf{+ A l} / \mathbf{+ A l}$ \\
\hline IAC 62 & $317.01 \mathrm{bcAB}$ & $337.07 \mathrm{aA}$ & $268.50 \mathrm{cAB}$ & $256.62 \mathrm{bB}$ \\
IAPAR 59 & $368.04 \mathrm{abAB}$ & $337.90 \mathrm{aB}$ & $441.98 \mathrm{aA}$ & $373.24 \mathrm{aAB}$ \\
Obatã IAC-1669/20 & $414.38 \mathrm{aA}$ & $323.63 \mathrm{aBC}$ & $382.64 \mathrm{abAB}$ & $307.29 \mathrm{abC}$ \\
Oeiras MG-6851 & $281.65 \mathrm{cA}$ & $300.16 \mathrm{aA}$ & $316.84 \mathrm{bcA}$ & $318.61 \mathrm{abA}$ \\
\hline \multirow{2}{*}{ Cultivars } & \multicolumn{4}{c}{$\mathbf{R L} \mathbf{( c m})^{*}$} \\
\cline { 2 - 5 } & $\mathbf{- A l} / \mathbf{- A l}$ & $\mathbf{- A l} / \mathbf{+ A l}$ & $\mathbf{+ A l} / \mathbf{- A l}$ & $\mathbf{+ A l} / \mathbf{+ A l}$ \\
\hline IAC 62 & $6.49 \mathrm{aA}$ & $6.96 \mathrm{aA}$ & $6.87 \mathrm{bA}$ & $7.40 \mathrm{aA}$ \\
ObPR 59 & $6.20 \mathrm{aA}$ & $5.12 \mathrm{aA}$ & $6.93 \mathrm{bA}$ & $6.99 \mathrm{aA}$ \\
Oeiras MG-6851 & $7.16 \mathrm{aAB}$ & $6.85 \mathrm{aB}$ & $9.33 \mathrm{aA}$ & $6.77 \mathrm{aB}$ \\
\hline
\end{tabular}

${ }^{(1)}$ Means followed by the same uppercase letter in the line and lower case letter in the column do not differ by the Tukey test at $1 \%{ }^{(* *)}$ and $5 \%^{(*)}$, for the same characteristic evaluated. (- $\left.\mathrm{Al} /-\mathrm{Al}\right)$ : germination and growth in the absence of $\mathrm{Al} ;(-\mathrm{Al} /+\mathrm{Al})$ : only growth in the presence of $\mathrm{Al} ;(+\mathrm{Al} /-\mathrm{Al})$ : only germination in the presence of $\mathrm{Al} ;(+\mathrm{Al} /+\mathrm{Al})$ : germination and growth in the presence of Al.

Many studies have shown that root growth inhibition is the most rapid visible symptom of aluminum toxicity in the plants, resulting in root system reduction and injuries, likely leading to mineral deficiency and water stress (Degenhardt et al., 1998). In the coffee cultivars in the present study, a significant difference was observed in root length (RL) only in the treatment $+\mathrm{Al} /-\mathrm{Al}$, with the cultivars Obatã IAC-1669/20 and Oeiras MG6851 presenting higher RL (Table 2). For these cultivars, the presence of aluminum in the solution during the germination might have stimulated the root growth, with the highest increase occurring in this phase, but not in the treatment $+\mathrm{Al} /+\mathrm{Al}$, where the presence of ion in the growth phase of the seedlings negatively affected RL, differing significantly only from the treatment $+\mathrm{Al} /-\mathrm{Al}$. In the remaining treatments $(-\mathrm{Al} /-\mathrm{Al}$ and- $\mathrm{Al} /+\mathrm{Al})$, this cultivar's RL was lower, likely due to the absence of aluminum during germination, since, at the concentration of $0.83 \mathrm{mmol} \mathrm{L}^{-1}$. Al was not toxic for this cultivar during the germination and stimulated primary root growth. However, this cultivar was sensitive to the presence of $\mathrm{Al}$ during the growth phase, whose treatments $(-\mathrm{Al} /+\mathrm{Al}$ and $+\mathrm{Al} /+\mathrm{Al}$ ) differed from the others with lower RL values (Table 2). This response was more evident in Table 3 , showing a high percentage of negative variation in the root length of the cultivar Obatã IAC-1669/20 which germinated in the presence of aluminum, likely as a result of stimulus on the RL of the primary root during this cultivar's germination, promoting root elongation under hydroponics in the absence of $\mathrm{Al}$ while inhibiting it under hydroponics in the presence of the same cation. Mistro et al. (2007) observed that the relative tolerance index value of cultivar Obatã IAC-1669/20 was reduced, showing the sensitivity of this cultivar to aluminum, compared to cultivar Catuaí Amarelo IAC 62, suggesting tolerance of 
this cultivar to aluminum at the concentration of $0.83 \mathrm{mmol} \mathrm{L}^{-1}$. This concentration was equivalent to $45 \mathrm{mg} \mathrm{L}^{-1}$ of $\mathrm{Al}^{3+}$ or $0.5 \mathrm{cmol}_{\mathrm{c}} \mathrm{dm}^{-3}$, corresponding to the classification of the mean content of the element in soil, which varied from 0.4 to $1.0 \mathrm{cmol}_{\mathrm{c}} \mathrm{dm}^{-3}$ (Fullin and Dadalto, 2001). In corn genotypes, the presence of toxic aluminum $(100 \%$ of aluminum saturation) did not significantly reduce the diameter and height of stem, leaf area, dry matter of aerial parts, total dry matter and yield (Souza et al., 2000).

RL of cultivars Catuaí Amarelo IAC 62 and Iapar 59 did not differ significantly in the presence or absence of aluminum at different phases, showing that these cultivars presented some mechanism of tolerance to aluminum, since treatment $+\mathrm{Al} /+\mathrm{Al}$ did not differ from the control (Table 2) and root growth of these cultivars was stimulated in the presence of aluminum (Table 3). Benin et al. (2004) evaluated oat genotypes and observed root growth retaking values that allowed a perfect discrimination between the sensitive and tolerant genotypes. Similar results were obtained by Freire et al. (1987) in rice, by Baligar et al. (1990) in sorghum and in wheat by Costa et al. (2003).

Cultivar Oeiras MG-6851presented a higher RL in the treatments with the presence of aluminum during the germination, regardless of aluminum absence or presence during the seedling growth. Despite presenting a negative percentage of root length variation (Table 3 ), this cultivar presented some tolerance to aluminum at the concentration of $0.83 \mathrm{mmol} \mathrm{L}^{-1}$, due to the significant difference between the control and the $+\mathrm{Al} /+\mathrm{Al}$, treatments, with the latter presenting higher RL values. These results suggested that root system development during the seedling growth was influenced by the presence of aluminum during the germination phase for this cultivar.

For the characteristics evaluated such as height $(\mathrm{H})$, dry mass of the aerial part (DMAP) and root fresh mass and dry mass (RFM and DRM, respectively), there was no interaction between the coffee cultivars and presence and absence of aluminum at different initial development phases (Table $4 \mathrm{~A}$ and $\mathrm{B}$ ). In maize, a reduction was observed in the dry mass of the aerial part with increase of aluminum (Batista et al., 2009). Table 5 showed that the statistical difference between the means of the values obtained from the cultivars was significant for the four characteristics previously cited, pointing cultivar Catuaí Amarelo IAC 62 as presenting the lowest means, not differing statistically from cultivar Oeiras $\mathrm{MG}$ 6851, which presented the similar results. The seedlings of cultivars Iapar 59 and Obatã IAC $1669 / 20$ presented, thus, more general development. Although showing less development, based on these characteristics, cultivar Catuaí Amarelo IAC 62 was the only one that effectively presented primary root growth increase (Table 3), indicating its tolerance to aluminum.

Table 3 - Root length $(\mathrm{cm})$ of arabica coffee cultivar seedlings germinated in the absence and presence of aluminum and variation $(\%)$ in root length in response to absence $(-\mathrm{Al})$ and presence $(+\mathrm{Al})$ of aluminum in the nutritive solution.

\begin{tabular}{|c|c|c|c|}
\hline \multirow{2}{*}{$\begin{array}{l}\text { Cultivars germinated in the } \\
\text { absence of } \mathrm{Al}\end{array}$} & \multicolumn{2}{|c|}{$\mathrm{Al}\left(45 \mathrm{mg} \mathrm{L}^{-1}\right)$} & \multirow{2}{*}{$\begin{array}{c}\text { Variation }^{(1)} \\
(\%)\end{array}$} \\
\hline & $-A \mathbf{l}$ & $+\mathbf{A l}$ & \\
\hline IAC 62 & 6.49 & 6.96 & +7.24 \\
\hline Iapar 59 & 6.20 & 5.12 & -17.42 \\
\hline Obatã IAC-1669/20 & 7.16 & 6.85 & -4.33 \\
\hline Oeiras MG-6851 & 5.31 & 5.26 & -0.94 \\
\hline \multirow{2}{*}{$\begin{array}{l}\text { Cultivars germinated in the } \\
\text { presence of } \mathrm{Al}\end{array}$} & \multicolumn{2}{|c|}{$\mathrm{Al}\left(45 \mathrm{mg} \mathrm{L}^{-1}\right)$} & Variation $^{(1)}$ \\
\hline & $-A \mathbf{l}$ & $+\mathrm{Al}$ & $(\%)$ \\
\hline IAC 62 & 6.87 & 7.40 & +7.71 \\
\hline Iapar 59 & 6.93 & 6.99 & +0.87 \\
\hline Obatã IAC-1669/20 & 9.33 & 6.77 & -27.44 \\
\hline Oeiras MG-6851 & 8.86 & 7.67 & -13.43 \\
\hline
\end{tabular}


Table 4 - Height (H), dry mass of the aerial part (DMAP), root fresh mass (RFM) and root dry mass (RDM) of Coffea arabica ${ }^{(1)}$ seedlings.(A) different cultivars. (B) originated from seeds germinated in the absence and presence of aluminum and developed in the absence and presence of aluminum.

\begin{tabular}{lcccc}
\hline \multicolumn{5}{c}{ A } \\
\hline Cultivars & H (cm) & DMAP (mg) & RFM (mg) & RDM (mg) \\
\hline Catuaí Amarelo IAC 62 & $5.32 \mathrm{~b}$ & $82.14 \mathrm{c}$ & $71.01 \mathrm{~b}$ & $10.66 \mathrm{~b}$ \\
Iapar 59 & $6.17 \mathrm{a}$ & $109.28 \mathrm{a}$ & $84.30 \mathrm{a}$ & $13.04 \mathrm{a}$ \\
Obatã IAC-1669/20 & $6.21 \mathrm{a}$ & $99.96 \mathrm{ab}$ & $73.15 \mathrm{ab}$ & $12.90 \mathrm{a}$ \\
Oeiras MG-6851 & $5.77 \mathrm{ab}$ & $90.41 \mathrm{bc}$ & $61.80 \mathrm{~b}$ & $10.82 \mathrm{~b}$ \\
\hline \multicolumn{5}{c}{$\mathbf{B}$} \\
\hline Aluminum & H (cm) & DMAP (mg) & RFM (mg) & RDM (mg) \\
\hline - Al / - Al & $5.97 \mathrm{ab}$ & $94.45 \mathrm{a}$ & $87.98 \mathrm{a}$ & $11.63 \mathrm{~b}$ \\
- Al / + Al & $5.71 \mathrm{ab}$ & $99.38 \mathrm{a}$ & $58.37 \mathrm{~b}$ & $11.01 \mathrm{~b}$ \\
$+\mathrm{Al} /$ - Al & $6.22 \mathrm{a}$ & $95.51 \mathrm{a}$ & $83.45 \mathrm{a}$ & $13.47 \mathrm{a}$ \\
$+\mathrm{Al} /+\mathrm{Al}$ & $5.57 \mathrm{~b}$ & $92.45 \mathrm{a}$ & $60.47 \mathrm{~b}$ & $11.31 \mathrm{~b}$ \\
\hline
\end{tabular}

${ }^{(1)}$ Means followed by the same letter in the column do not differ by theTukey test at 1\%. (- $\left.\mathrm{Al} / \mathrm{-} \mathrm{Al}\right)$ : germination and growth in the absence of $\mathrm{Al} ;(-\mathrm{Al} /+\mathrm{Al})$ : only growth in the presence of $\mathrm{Al} ;(+\mathrm{Al} /-\mathrm{Al})$ : only germination in the presence of $\mathrm{Al} ;(+\mathrm{Al} /+$ $\mathrm{Al})$ : germination and growth in the presence of $\mathrm{Al}$.

Except for DMAP, which was not sensitive, aluminum affected significantly all the characteristics evaluated (Table 4B). Vasconcelos et al. (2002) reported that DMAP was an insensitive parameter in detecting differential tolerance to aluminum. The lowest height value of the aerial part of the seedlings was observed in the treatment $+\mathrm{Al} /+\mathrm{Al}$, but this treatment did not differ from the control and from the $-\mathrm{Al} /+\mathrm{Al}$ treatments. However, the absence of $\mathrm{Al}$ in the two phases of development (-Al / - $\mathrm{Al})$ and its presence in the seedling development phase $(-\mathrm{Al} /+\mathrm{Al}$ and $+\mathrm{Al} /+\mathrm{Al})$ affected $\mathrm{H}$ negatively. The highest RFM was observed in the control (-Al / - Al) and $+\mathrm{Al} /$ - $\mathrm{Al}$ treatments that differed from the others. On the other hand, the RDM of the seedlings was significantly higher only in treatment $+\mathrm{Al} /-\mathrm{Al}$.

The results obtained suggested that the presence of aluminum in the germination did not induce the cultivars to tolerate it, even at more advanced stages of development. Although many studies on the nutritive solution have been representative of field conditions, it could be suggested that these cultivars be evaluated under these conditions and at more advanced stages of development, since the response of the cultivars to aluminum toxicity could change from one stage to the other, as well as their nutritional needs.

\section{CONCLUSIONS}

The concentration of $0.83 \mathrm{mmol} \mathrm{L}^{-1}$ of $\mathrm{Al}^{3+}$ resulted difference in the arabica coffee cultivars.
Based on the evaluation of the characteristic root length during the initial seedling growth, the cultivars Catuaí Amarelo IAC 62 and Iapar 59 could be considered tolerant to aluminum; cultivar Oeiras MG-6851 presented intermediary tolerance, and cultivar Obatã IAC-1669/20 was sensitive to the element.

The differential tolerance presented by the coffee cultivars in the presence of aluminum during the initial development of the seedlings occurred regardless of the presence of $\mathrm{Al}$ in the germination phase.

\section{ACKNOWLEDGEMENTS}

We thank FAPES/CAPES for granting a Master's scholarship to the first author.

\section{REFERENCES}

ABIC. História do café. Available at: $<$ http://www.abic.com.br/> Accessed on 01 nov. 2006.

Baligar, V. C.; Anghinoni, I.; Pitta, G. V. E.; Santos, H. L.; Cunha Filho, E.; Schaffert, R. E. (1990), Efeito de diferentes níveis de alumínio na solução nutritiva sobre a composição da fração nitrogenada em sorgo. R. Bras. Fisiol. Veg., 2, 47-52.

Baligar, V. C.; Santos, H. L.; Pitta, G. V. E.; Cunha Filho, E.; Vasconcellos, C. A.; Bahia Filho, A. F. C. (1989), Aluminum effects on growth, grain yields and nutrient use effciency ratios in sorghum 
genotypes. Plant and Soil, Netherlands, 116, 257 264.

Batista, M. A; Pinto, J. C.; Costa, A. C. S. da; Tormena, C. A.; Bonato, C. M.; Batista, M. F. (2009), Mineral composition and dry mass production of the corn plants in response to phosphorus sources and aluminum concentration. Braz. Arch. Biol. Technol. [online]. 52, 541-548.

Benin, G.; Carvalho, F. I. F. de; Oliveira, A. C.; Silva, J. A. G. da; Lorencetti, C.; Maia, M. B.; Marchioro, V. S.; Freitas, F.; Hartwing, I. (2004), Uma proposta de seleção para caracteres quantitativos e qualitativos em aveia. Ci. Rural, 34, 701-706.

Braccini, M. C. L.; Martinez, H. E. P.; Braccini, A. L. (2000a), Avaliação de linhagens de cafeeiros quanto à tolerância ao alumínio pelo método do papelsolução. Bragantia, 59, 221-226.

Braccini, M. C. L.; Martinez, H. E. P.; Braccini, A. L.; Mendonça, S. M. (2000b), Avaliação do pH da rizosfera de genótipos de café em resposta à toxidez de alumínio no solo. Bragantia, 59, 83-88.

CONAB. Companhia Nacional de Abastecimento. Acompanhamento da Safra Brasileira: Café Safra 2008, primeira estimativa, janeiro/2008. Brasília: CONAB, 2008. 10 p. Available at: <http://www.conab.gov.br/conabweb/download/safra /Boletim.pdf> Accessed on 20 fev. 2008.

Costa, A.; Campos, L. A. C.; Riede, C. R. (2003), Reaction of wheat genotypes to soil aluminum differential saturations. Braz. Arch. Biol. Technol. [online]. 46, 19-25.

Degenhardt, J.; Larsen, P. B.; Howell, S. H.; Kochian, L.V. (1998), Aluminum resistance in the Arabidopsis mutant alr-104 is caused by an aluminum-induced increase in rhizosphere pH. Plant Physiology, 117, 19-27.

Dornelles, A. L. C.; Carvalho, F. I. F. de; Federizzi, L. C.; Sereno, M. J. C. de M.; Amaral, A.; Mittelmann, A. (1997), Avaliação simultânea para tolerância ao alumínio e sensibilidade ao ácido giberélico em trigo hexaplóide. Pesq. Agropec. Bras., 32, 893-896.

Euclydes, R. F. (2004), Sistema para análises estatísticas (SAEG 9.0). Viçosa: FUNARBE, Universidade Federal de Viçosa, Viçosa.

Fageria, N. K. (1998), Otimização da eficiência nutricional na produção das culturas. Rev. Bras. Eng. Agríc. Ambiental., 2, 6-16.

Foy, C. D.; Chaney, R. L.; White, M. C. (1978), The physiology of metal toxicity in plants. Annual Review Plant Physiology, 29, 511-566.

Freire, L. R.; Amaral Sobrinho, N. M. B.; Fernandes, M. S.; Ribeiro, M. E. S.; Santos, J. C. P. dos. (1987), Efeito de alumínio nas raízes de arroz cultivado em solução nutritiva. Pesq. Agropec. Bras., 22, 459-464.
Fullin, E. A.; Dadalto, G. G. (2001), Avaliação da fertilidade do solo e do estado nutricional das plantas. In: Dadalto, G. G.; Fullin, E. A. Manual de recomendação de calagem e adubação para o estado do Espírito Santo - $4^{\mathrm{a}}$ aproximação. Vitória: SEEA / INCAPER, pp. 21-55.

Hoagland, D. R.; Arnon, D. I. (1950), The water-culture method for growing plants without soil. Berkeley: California Agricultural Experiment Station, 32 p. (Circular, 347).

Justino, G. C.; Cambraia, J.; Oliva, M. A.; Oliveira, J. A. (2006), Absorção e redução de nitrato em duas cultivares de arroz na presença de alumínio. Pesq. Agropec. Bras., 41, 1285-1290.

Malavolta, E.; Favarin, J. L.; Malavolta, M.; Cabral, C. P.; Heinrichs, R.; Silveira, J. S. M. (2002), Repartição de nutrientes nos ramos, folhas e flores do cafeeiro. Pesq. Agropec. Bras., 37, 1017-1022.

Marschner, H. (2003), Mineral nutrition of higher plants. 2.ed. London: Academic Press, 889 p.

Mendonça, R. J.; Cambraia, J.; Oliva, M. A.; Oliveira, J. A. (2005), Capacidade de cultivares de arroz de modificar o $\mathrm{pH}$ de soluções nutritivas na presença de alumínio. Pesq. Agropec. Bras., 40, 447-452.

Menosso, O. G.; Costa, J. A.; Anghinoni, I.; Bohnen, H. (2000), Tolerância de genótipos de soja ao alumínio em solução. Pesq. Agropec. Bras., 35, 2157-2166.

Mistro, J. C.; Fazuoli, L. C.; Gallo, P. B. (2007), Comportamento de cultivares de café arábica em solos ácidos e corrigidos. O Agronômico, 59, 37-38.

Rheinheimer, D. dos S.; Santos, E. J. da S.; Kaminsky, J.; Xavier, J. M. (2000), Aplicação superficial de calcário no sistema plantio direto consolidado em solo arenoso. Ci. Rural, 30, 263-268.

Souza, J. R. P. de; Guimaraes, M. F. de; Muller, M. M. L.; Santos, C. H. dos. (2000), Morphological alterations of corn (Zea mays L.) plants in response to aluminum toxicity in the soil. Braz. Arch. Biol. Technol. [online]. 43, pp 0-0.

Vasconcelos, S. S.; Rossielo, R. O. P.; Jacob-Neto, J. (2002), Parâmetros morfológicos para estabelecer tolerância diferencial à toxicidade de alumínio em cultivares de arroz. Pesq. Agropec. Bras., 37, 357363.

Received: March 19, 2009; Revised: January 02, 2010; Accepted: June 15, 2011. 


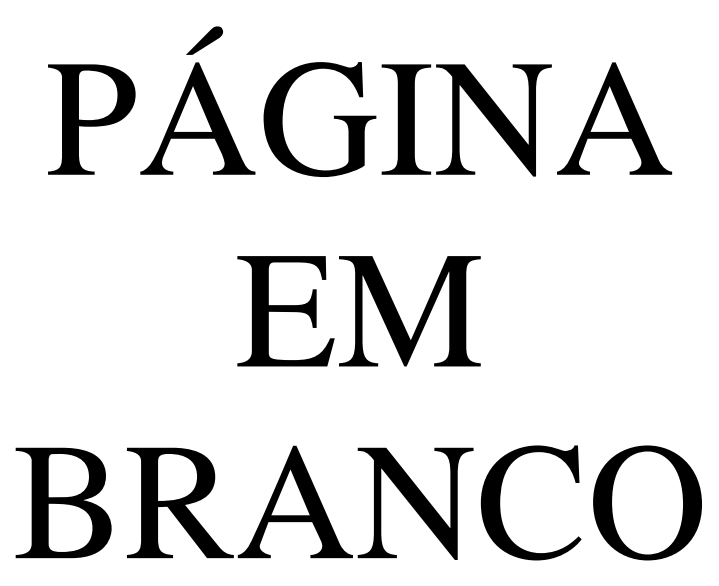

